\title{
In Vivo Yam (Dioscorea spp.) Vine Multiplication Technique: The Plausible Solution to Seed Yam Generation Menace
}

\author{
Emmanuel Otoo ${ }^{1}$, T. G. Anyakanmi ${ }^{2}$, Hideniko Kikuno $^{2} \&$ Robert Asiedu $^{2}$ \\ ${ }^{1}$ Crops Reseach Institute, The Council for Scientific and Industrial Research, Kumasi, Ghana \\ ${ }^{2}$ International Institute for Tropical Agriculture, Ibadan, Nigeria \\ Correspondence: Emmanuel Otoo, Crops Reseach Institute, The Council for Scientific and Industrial Research, \\ P.O. Box 3785, Kumasi, Ghana. E-mail: otooemmanuel@gmail.com
}

$\begin{aligned} & \text { Received: November 5, } 2015 \\ & \text { Accepted: December 10, } 2015 \quad \text { Online Published: January 15, } 2016 \\ & \text { doi:10.5539/jas.v8n2p88 }\end{aligned} \quad$ URL: http://dx.doi.org/10.5539/jas.v8n2p88

\begin{abstract}
A study was conducted to develop a vine multiplication package for generation of seed yam. The parameters assessed for the package were rooting media of the vine cuttings, yam variety and nutrient supplementation to the mother plant to generate minitubers. Nine varieties of yams were planted in 4 media types (soil, soil + sawdust, soil + carbonized rice husk and cocopeat) and 2 levels of nutrient supplementation (no supplementation and supplementation) using RCBD with 3 replications. The study was conducted over 2-year period. Boosting the nutrient status of the mother plant before excising the vines proved to enhance establishment and subsequently the yield of the vine cuttings. Incorporation of biochar in the planting media also enhanced establishment of the vine cuttings and subsequent yields. Success of the vine multiplication techniques also proved to be variety dependent. An in vivo vine multiplication package has been developed for yam seed generation.
\end{abstract}

Keywords: biochar, Ghana, yam, vine

\section{Introduction}

Yam is a multi species crop and considered as one of the most important staple food crops of sub-Saharan Africa that provide valuable source of dietary carbohydrate and income (Bhattacharjee et al., 2011). Seeds, vines or tubers can be used biologically to propagate yams. However, for commercial purposes yam is mainly propagated by vegetative means through the use of whole tubers and different portions of tubers or seed yams from double harvesting of the crop (Otoo, 1980). Availability and cost of seed yam have been identified as a major limiting factor in the expansion of yam cultivation. Seed yams are not only expensive but also scarce (Ironkwe, 2005) accounting sometimes for as much as $63 \%$ of total variable cost of yam production and also bulky to transport (Manyong, 2000). Scarcity of seed tubers often results in unplanted mounds in farmers' fields and some farmers also keep a reserve batch of seed yams (up to a third of the quantity planted) for replacement of seeds that do not germinate (Aighewi, Akoroda, \& Asiedu, 2002).

These identified limitations have been attributed to the relatively low multiplication ratio of yams as compared to cereals. For example, multiplication ratio of maize is about 1:300 whilst in seed yams production using traditional method (use of whole tubers or parts of tubers) is 1:6-8; using minisetts technique is 1:20-40 and micropropagation technique is 1:200. These low multiplication ratios limit the rate of expansion in yam cultivations. It determines the rate at which yams generally could be disseminated to farmers especially improved varieties; and limits the expansion in yam cultivation. The search therefore in Ghana for alternative efficient and effective multiplication system has become imperative especially after the release of improved varieties in Ghana in 2005.

Currently, the existing three main methods of seed yams generation all have their pros and cons. These methods are milking or pricking, minisetts and micropropagation techniques.

The milking method results in the development of a cluster of small tubers or tubers of irregular shape. This is harvested at the end of season and depending on its size, 4-6 setts of 100-500 g could be obtained for planting. These planting materials are hardy and have good sprouting ability. This system also allows farmers to introduce yams into the market during the lean season especially for early maturing varieties such as pona and laribako, 
and hence attract good prices. This method of seed production is however inefficient due to the following reasons:

1. Yam tubers harvested are immature and hence have short longevity in storage;

2. It produces non-uniform shape seed yams;

3. Quantities of yam produced are inadequate to enhance expansion in production.

The yam minisett technique, which is an improvement over the traditional seed yam generation technique, is a system where a mother seed yam of 500-1000 $\mathrm{g}$ is cut into 20-40 pieces of $25 \mathrm{~g}$ or less yam setts. The minisetts must necessarily have a periderm and be treated with chemical protectants. The setts are either planted directly and staked or pre-sprouted before transplanting. Five to six months later 200-1000 g seed yams are harvested. Sawdust, topsoil, rotten palm, river sand and their mixtures are but a few of sprouting media used by various workers to obtain good and healthy sprouts through minisetts technique.

Even though the superiority of this system over the traditional double harvesting system has been proven by several workers and the system have been adopted in certain parts of Nigeria, farmers in Ghana have not. Several reasons were attributed to this. Among them were,

1. Poor sprouting and establishment of some elite yam cultivars like pona and laribako when multiplied by this method;

2. Long time lag between seed yam generation and availability for planting;

3. Uncertainty on appropriate time for raising nursery; and,

4. The generally poor understanding of the technique at the time of its introduction by major stakeholders such as farmers and extension agents who were to impact such knowledge to farmers.

The micropopagation techniques are feasible but expensive alternative method of seed yam generation. This involves the use of tissue culture techniques to rapidly multiply yam tubers. First plantlets are generated from vegetative parts of the plants under aseptic conditions. The plantlets are used to generate microtubers and ultimately minitubers. It has a multiplication ratio of 1:200-400. It has the singular advantage of being capable of eliminating viruses and produce certified virus-free material. It is however relatively expensive in terms of manpower and technical requirements for its execution.

The need therefore for an alternative system of seed yam generation, which is efficient and effective as well as cost effective, cannot be over-emphasized. Yam vine cuttings unlike sweetpotato's are difficult to root and establish. Work done elsewhere especially in Japan for similarly hard-to-root plants has shown that planting such cuttings in soils fortified with carbonized rice husk, significantly improves rooting and establishment. This has successfully been validated in yams in Ghana (Otoo, Schiwachi, Kikuno, \& Ayankami, 2011).

Availability of "clean" planting material is the greatest limitation in West Africa. Farmers in West Africa bulk planting material (tubers, vines and setts) from both infected (symptomatic) and asymptomatic plants and use them indiscriminately for planting. This practice not only contributes to the spread of pests and pathogens along with the planting material but also affects the yields and gradual decline in source material (Bhattacharjee et al., 2011). Traditionally farmers obtain seed tubers by selecting small tubers (e.g. 300-500 g) from each harvest (unfortunately these are often those produced by diseased plants); using tubers from the second harvest of early maturing varieties; using small tubers from varieties that produce multiple tubers per stand; or by cutting ware tubers into pieces (Aighewi, Akoroda, \& Asiedu, 2002).

The yam vine multiplication technique in vivo has therefore been identified as a suitable alternative since it can increase the multiplication ratio of yams to 1:240 with minimal input (Otoo, Schiwachi, Kikuno, \& Ayankami, 2011). The demonstrated high multiplication ratio of this technique must be extensively disseminated to enhance production and productivity of yams. This study however has developed a complete package of all the good agronomic practices that will ensure effective and efficient establishment and therefore generation of seed yam through the yam vine multiplication techniques and enhance its adoption.

The propagation of yams by vine cuttings is a very useful technique for rapid multiplication of desirable clonal materials (Peter, 2006; Kikuno et al., 2006). Vine cuttings of D. rotundata can be used to produce mini tubers within 100-120 days that could be used in germplasm exchange and for production of seed yams (Kikuno et al., 2006). The only limiting factor militating against the use of vine cuttings for mini tuber generation is the poor establishment of yam vine cuttings. This limitation has been partially addressed by various workers (Kikuno et al., 2006; Anyankanmi \& Agele, 2010; Otoo, Schiwachi, Kikuno, \& Ayankami, 2011). This breakthrough was mainly attributable to the application of carbonized rice husk in the planting media. Carbonized rice husk is a 
form of biochar. Biochar is charcoal produced for the primary purposes of improving soil fertility and sequestering carbon (Lehmann \& Joseph, 2009). Biochar primarily is produced by heating up biomass in the absence of oxygen. It can be made from a wide variety of carbon rich feed-stocks e.g. Nut shells, grain husks, crop residues, wood, and even manure. Biochar, due to it aromatic structure, is highly resistant to abiotic and biotic degradation (Zimmerman, 2009). As a result it can remain in the soil for hundreds and even thousands of years (Glaser, 2001). The major benefit obtained in applying biochar is to increase the soil's water holding capacity (Glaser, 2001, Glaser, Guggenberger, \&, Zech, 2002; Downie, Crosky, \& Munroe, 2009).

The broad objective of this study therefore was to identify efficient and cost effective ways of increasing the multiplication ratio of yams. The specific objective was to determine the best package for an in vivo yam vine multiplication.

\section{Materials and Methods}

Over 2-year period, a study was conducted at CSIR-Crops Research Institute on-station fields aimed at developing an-easy to use package for yam vine multiplication. The yam materials used was Dioscorea rotundata varieties. The soil and climatic characteristics of the test sites are presented in Table 1.

Table 1. Climatic and soil characteristics of the test location

\begin{tabular}{ll}
\hline Characteristic & Location (Fumesua) \\
\hline Agroecology Zone & Humid forest agro- ecological zone \\
Coordinates & $6^{\circ} 41^{\prime} \mathrm{N}, 1^{\circ} 28^{\prime} \mathrm{W}$ \\
Soil type & Ferric Acrisol, Asuansi series Asuansi series with c. $5 \mathrm{~cm}$ thick top layer of dark \\
& grey gritty loam to gritty clay loam \\
Slope & $2-6 \%$ \\
Rainfall & Bimodal rainfall pattern, $1190-1650 \mathrm{~mm}$ with an average of $1345 \mathrm{~mm} /$ year \\
Major & Mar-July; peak in June \\
Minor & Sep-Nov; peak in Oct \\
Temperature & $22-31^{\circ} \mathrm{C}$ \\
& $($ Adu \& Asiamah, 1992) \\
\hline
\end{tabular}

A $9 \times 4 \times 2$ factorial experiment of variety, media, and nutrient supply were conducted over two-year period (Table 2). The experimental design used was RCB with 3 replications.

To enhance the multiplication ratio of yams, vine multiplication techniques for seedyam multiplication was developed and disseminated to farmers and Agricultural Extension Agents. The technique is an effective and efficient means of generating seedyams.

Table 2. Treatments evaluated over 2-year period at Fumesua, Ghana

\begin{tabular}{|c|c|c|}
\hline \multicolumn{3}{|c|}{ Factor } \\
\hline Variety/Cultivar & Planting Media & Nutrient \\
\hline 1. CRI Pona & 1. Soil & 1. No Fertilization Supplementation (NFS) \\
\hline 2. Mankrong Pona & $\begin{array}{l}\text { 2. Soil + Carbonized Rice Husk in a } \\
\text { ratio of } 3: 1\end{array}$ & $\begin{array}{l}\text { 2. Fertilizer Supplementation (FS) N-P-K-Mn-S } \\
15-25-8-0.2-0.4\end{array}$ \\
\hline 3. CRI Kukrupa & 3. Soil+ Sawdust in a ratio of $3: 1$ & \\
\hline 4. Dente & 4. Coco-peat & \\
\hline 5. Chenchito & & \\
\hline 6. TDr 95/19177 & & \\
\hline 7. Muchumudu & & \\
\hline 8. Serwa & & \\
\hline 9. Pona & & \\
\hline
\end{tabular}

The nutrient treatment consisted of no fertilization supplementation (NFS) and supplemental foliar fertilization 
(FS) of NPK 15-25-8 with micronutrient of Mn-S of 0.2-0.4 (SF) to the mother plant from which the vine cuttings were to be obtained at 2 weeks before vine cutting. Each plot consisted of 1000 stands. Two-node cuttings were excised from lateral branches of between 8-12 weeks old yam plants and planted in the media in a PE bag. The plants were initially shaded to reduce stress on planted cuttings, and the shades were removed after 6 weeks, and the plants staked by connecting the vines to the mounted poles by ropes. The Carbonized Rice Husk was prepared by as per Otoo, Schiwachi, Kikuno and Ayankami, 2011. A vine was considered established if there is no visible sign of necrosis at 2 weeks after planting. The vines were all given an initial boost by applying NPK 15-25-8 foliar fertilization 2 weeks after establishment to encourage new shoot and leaves formation. They were subsequently provided with foliar fertilizer with high P and K formulation (NPK 7-35-8) to encourage nutrient uptake and tuber bulking.

Data was taken on establishment, number of plants with new leaves/shoots after planting (used in calculating the percentage of plants with new leaves/shoot per treatment), pest and diseases and number and weight of tubers.

Data analysis

Analysis of Variance was conducted on all parameters using GLM procedure of SAS (Version 9.1). Significant difference between means was tested using SED at 5\% level of significance. Both percentage data on establishment and new shoot development were Arc Sine Transformed before analysis.

\section{Results}

Significant variety differences were observed with respect to establishment (Table 3). Mean establishment ranged from $78 \%$ (Dente) to $85.7 \%$ (TDr 95/19177) with a mean of $82.8 \%$. Generally, boosting the nutrient status of the mother plants before excising the vine cuttings through nutrient supplementation significantly improved the establishment from $74.3 \%$ to $91.2 \%$. Without nutrient supplementation, mean establishment of vine cuttings ranged from $65.3 \%$ (Dente) to $81 \%$ (Pona) with a mean of $74.3 \%$. With nutrient supplementation, it ranged from $88.7 \%$ in Serwa to $93.3 \%$ in CRIPona with a mean of $91.2 \%$.

Establishment of vine cuttings with respect to varieties and nutrient supplementation was also significantly $(\mathrm{p}<$ 0.05 ) different. With no supplementation, establishment generally ranged from $65.3 \%$ (Dente) to $81.0 \%$ (Pona) with a mean of $74.3 \%$; however when it was boosted with supplemental fertilization of the mother plants before cutting the vines, establishment was significantly $(\mathrm{p}<0.05)$ raised the establishment to $88.7 \%$ (Serwa) and 93.3\% (CRI Pona) with a mean of $91.2 \%$. Highly significant variety and supplemental fertilization interaction effect were also observed for establishment, which is reflected in percent improvement on establishment. The order of establishment without supplementation was Pona, TDr 95/191977, Muchumdu, Mankrong Pona, CRI Pona, CRI Kukrupa, Serwa and Dente in decreasing order of establishment. This order changed significantly when the mother plant was boosted with supplementation before excising the vines. CRI Pona, CRI Kukrupa, Mankrong Pona, Muchumudu, Chenchito, Dente, Pona, and Serwa in decreasing order of establishment. Again, when the mother plants were boosted with supplementation before excising the vines, TDr 85/19177, CRIPona, Pona, Muchumudu, Chenchito are all recording establishment figures of over $90 \%$ with no significant differences amongst them. The percent improvement on establishment as a result of supplementation ranged from $10.5 \%$ in Pona to $38.9 \%$ in Dente with a mean of $22.8 \%$. Dente, Chenchito, Serwa, CRIKukrupa, CRIPona, Mankrong Pona, Muchumudu, TDr 95/19177, and Pona, Muchumudu, were the most beneficiaries of supplementation in the decreasing order of importance. 
Table 3. Effect of nutrient supplementation on mother plant to generate minitubers on mean establishment of vine cuttings 2 WAP

\begin{tabular}{lllll}
\hline Variety/Treatment & NFS & FS & Mean & Per cent Improvement \\
\hline CRI Pona & 76.8 & 93.3 & 85.1 & 21.5 \\
Mankrong Pona & 78.2 & 91.9 & 85.1 & 17.5 \\
CRI Kukrupa & 74.2 & 92.6 & 83.4 & 24.8 \\
Dente & 65.3 & 90.7 & 78.0 & 38.9 \\
Chenchito & 66.4 & 91.3 & 78.9 & 37.5 \\
TDr 95/19177 & 80.2 & 91.2 & 85.7 & 13.7 \\
Muchumudu & 78.4 & 91.7 & 85.1 & 17 \\
Serwa & 68.2 & 88.7 & 78.5 & 30.1 \\
Pona & 81 & 89.5 & 85.3 & 10.5 \\
Mean & 74.3 & 91.2 & 82.8 & 22.8 \\
SED Variety & - & - & 2.2 & - \\
SED Variety $\times$ Supplementation & 3.4 & & - & - \\
\hline
\end{tabular}

Highly significant differences were also observed in the media type used for culturing the vine cuttings (Table 4). Generally, soil + CRH recorded significantly $(\mathrm{P}<0.05)$ higher establishment followed by Coco peat, soil + sawdust and soil in decreasing order of establishment.

Table 4. Effect of soil media on mean establishment of vine cuttings 2 weeks after planting (WAP)

\begin{tabular}{llllll}
\hline Variety/Treatment & Soil & Soil+Sawdust & Soil+CRH & Cocopeat & Mean \\
\hline CRI Pona & 77.8 & 81.6 & 94.3 & 86.6 & 85.1 \\
Mankrong Pona & 76.0 & 86.2 & 93.3 & 84.8 & 85.1 \\
CRI Kukrupa & 73.0 & 81.7 & 93.0 & 85.9 & 83.4 \\
Dente & 70.1 & 75.0 & 86.6 & 80.3 & 78.0 \\
Chenchito & 76.5 & 74.8 & 85.3 & 78.8 & 78.9 \\
TDr 95/19177 & 73.4 & 83.1 & 95.1 & 91.3 & 85.7 \\
Muchumudu & 79.4 & 82.4 & 93.2 & 85.2 & 85.1 \\
Serwa & 71.3 & 75.8 & 87.3 & 79.4 & 78.5 \\
Pona & 81.6 & 82.0 & 92.8 & 84.7 & 85.3 \\
Mean & 75.5 & 80.3 & 91.2 & 84.1 & 82.8 \\
SED & 2.1 & & & & \\
\hline
\end{tabular}

No significant interactions were however observed between variety and soil media as well as supplementation and soil media for all parameters studied.

There was significant $(\mathrm{P}<0.05)$ variety and nutrient supplementation main effects with respect to development of new leaves or shoots after establishment of the vine cuttings (Figure 1). Generally, varieties CRI Kukrupa, TDr 95/19177, Dente, Chenchito and Muchumudu had significantly more new leaves/shoots developing than Mankrong Pona, Pona, CRI Pona, which had very little new leaves. This effect was more pronounced in most of treatments where there was fertilizer supplementation before vine cuttings. No significant variety and supplementation interaction effect was also observed. No significant differences were also observed in number of new leaves/shoots formed with respect to soil media used. 


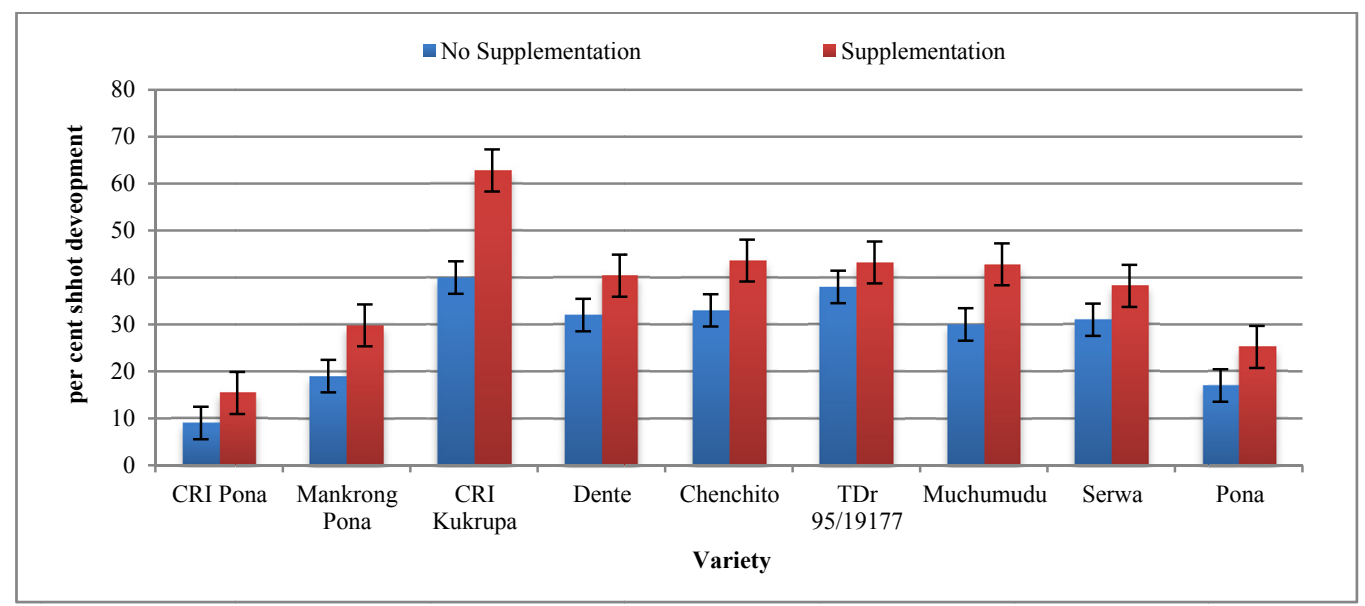

Figure 1. Percent new shoots development by variety and supplementation 30 days after planting vine cuttings

The yield of the vine cuttings was studied with respect to number of tubers and weight of tubers harvested (Figures 2 and 3) respectively. In Figure 2, significant differences were observed with variety, fertilizer supplementation and media main effects. Significant interaction effects were observed. Variety CRI Kukrupa had up to 6 tubers per stand followed by Mankrong Pona with mean number of tubers of 3.3, Pona 3.6, CRI Pona 1.5 and all the rest had single tuber per stand. Nutrient supplementation increased the number of tubers by $8.7 \%$ with the most gain observed in CRI Pona (33.3\%) followed by CRI Kukrupa (14.8\%).

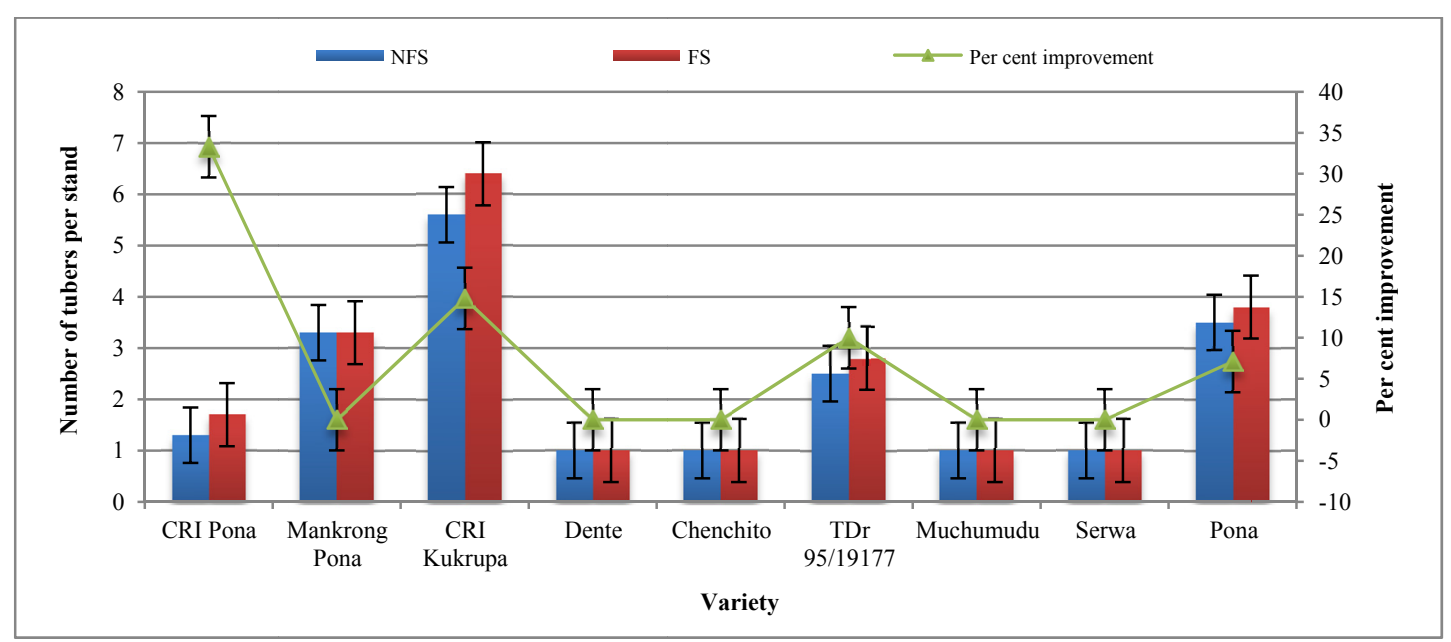

Figure 2. Effect of fertilizer supplementation on the number of minitubers per stand of vine cuttings at 120 days after planting

Generally more minitubers were generated from the soil+CRH media than the rest of the soil media (Fig 3). This was followed by Cocopeat, Soil and soil+ sawdust in that deceasing order of importance. 


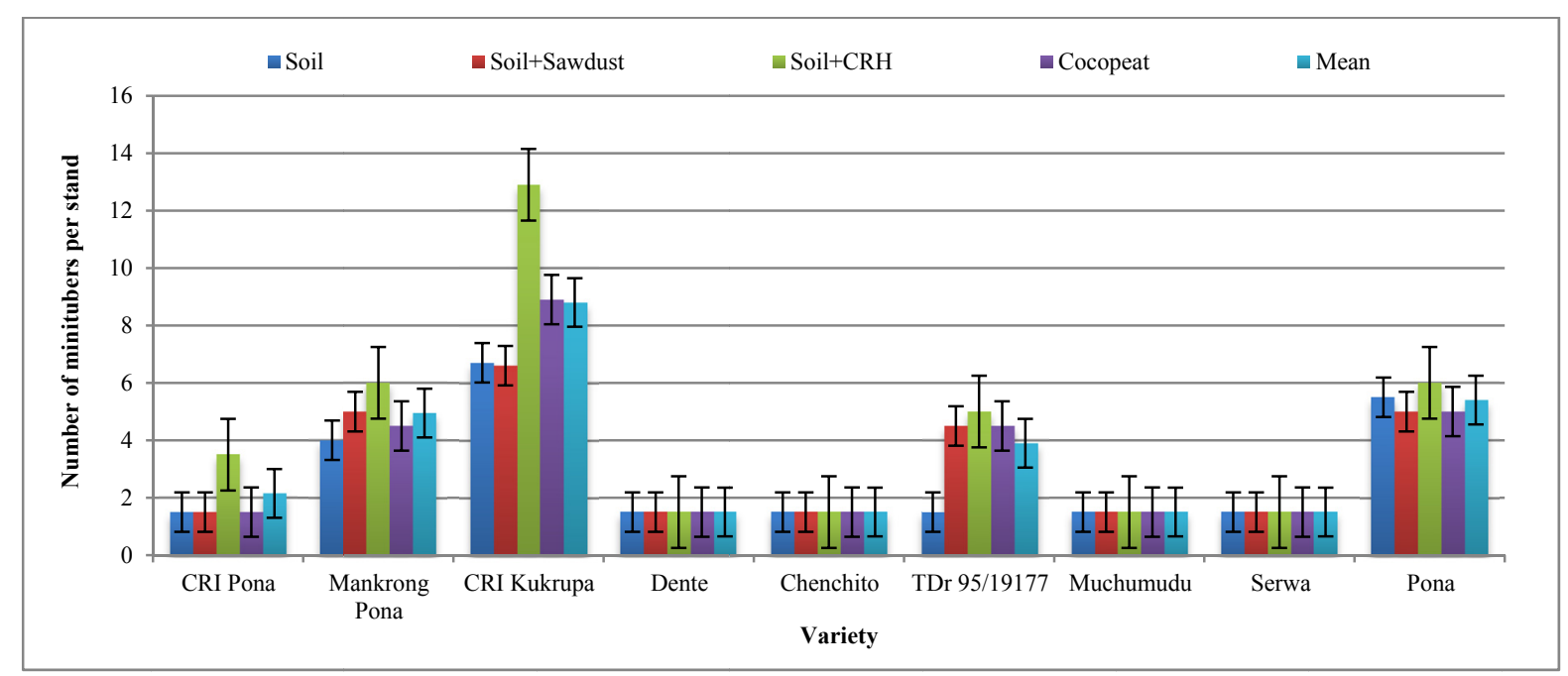

Figure 3. Effect of soil media on number of minitubers per stand of vine cuttings at 120 days after planting

Generally, the mean tuber weight ranged from $33.6 \mathrm{~g}$ (CRI Pona) to $49.2 \mathrm{~g}$ (Muchumudu) with a mean of $39.1 \mathrm{~g}$ (Figure 4). When no supplemental nutrient was applied the mean tuber weight of minitubers generated with respect to variety ranged from $25.0 \mathrm{~g}$ (CRI Pona) to $44.2 \mathrm{~g}$ (Muchumudu) with a mean of $32.5 \mathrm{~g}$. Similar trend was observed when supplemental nutrients were applied. The mean tuber weight ranged from 42.3 (CRI Pona) to $54.1 \mathrm{~g}$ (Muchumudu) with a mean of $45.8 \mathrm{~g}$. Supplemental nutrient application resulted in increased tuber weight ranging from 22.4-69.6\% for Muchumudu and CRI Pona respectively with a mean of 40.8\%. The soil media significantly influenced the tuber weight in all instances. When no nutrient supplement was applied, Soil $+\mathrm{CRH}$ media gave the highest tuber weight of $47.6 \mathrm{~g}$ followed by Coco-peat, soil and soil + sawdust. Similar trend was observed when supplemental nutrient was applied to the mother plant before excising the vines. With respect to per cent gin as a result of nutrient supplementation, CRIPona had the highest gain followed by Mankrong Pona, Chenchito, Dente, CRI Kukrupa, TDr 95/19177, Pona, Serwa and Muchumudu in that decreasing order of importance.

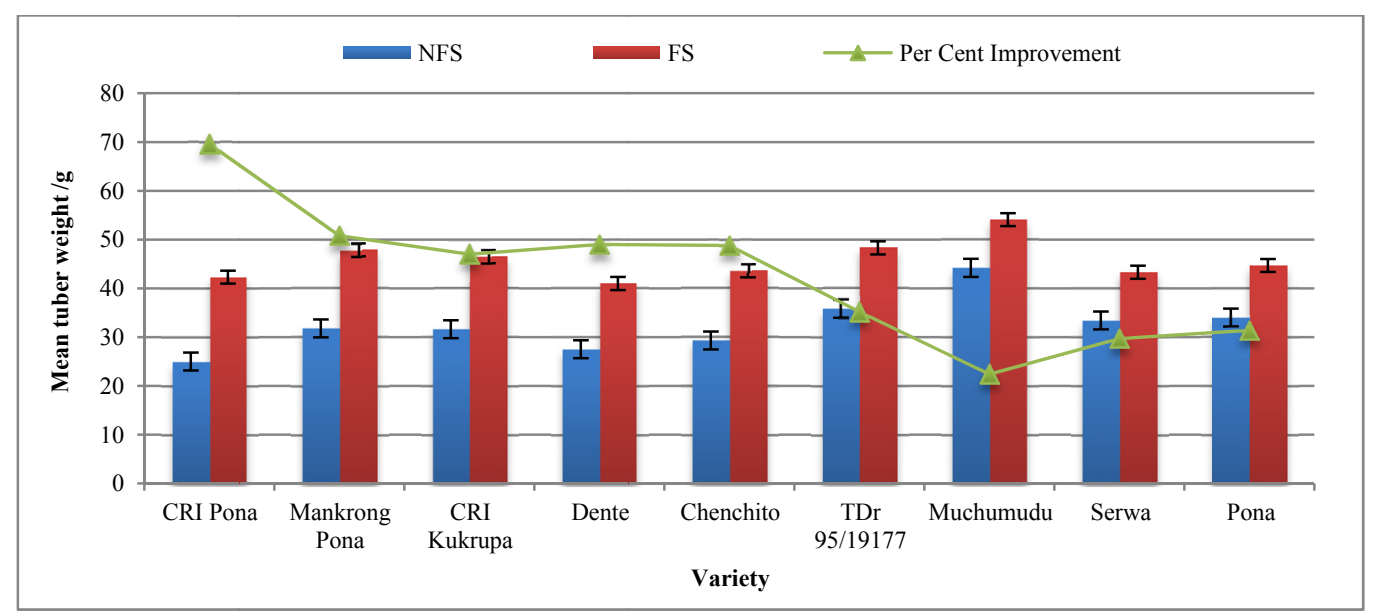

Figure 4. Effect of fertilizer supplementation on the mother plant on the mean minituber weight (g) of vine cuttings after 120 days of planting

Similar to the trend observed in number of minitubers with respect to soil media, the tuber weight was significantly $(\mathrm{p}<0.05)$ influenced by the soil media (Figure 5$)$. Soil $+\mathrm{CRH}$ media was the most productive media for vine multiplication with respect to mean tuber weight followed by cocopeat, soil and soil + sawdust in that order of decreasing importance. 


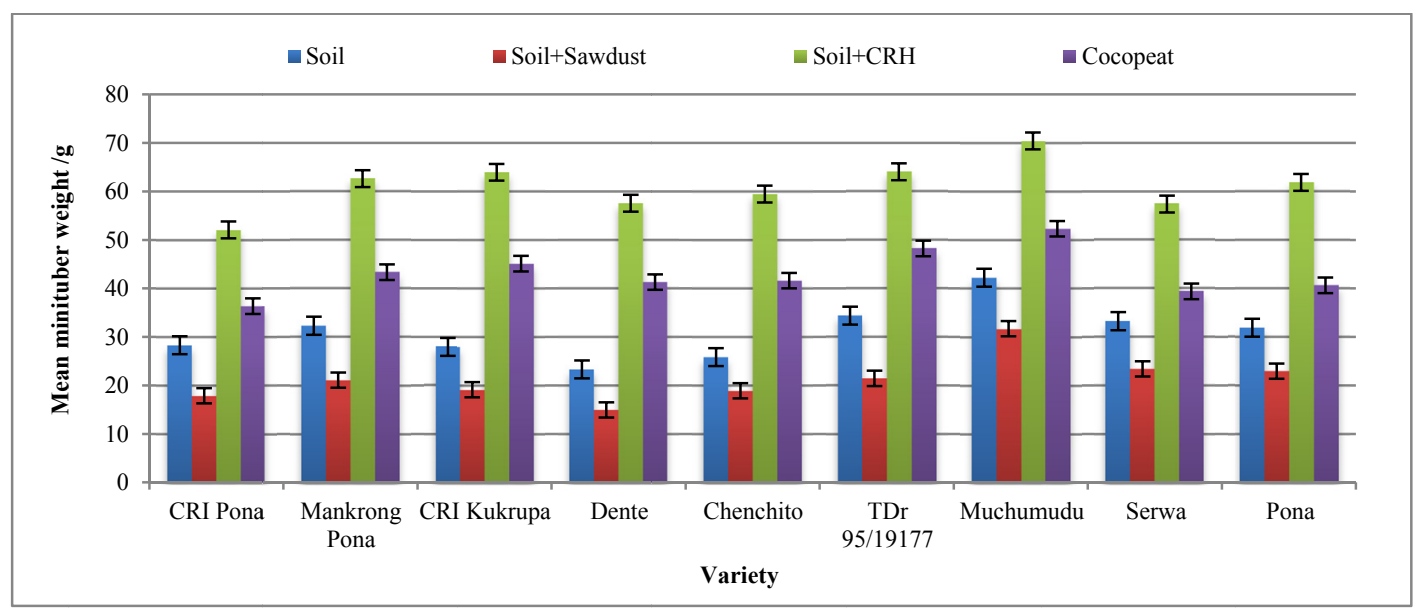

Figure 5. Effect of soil media on mean minituber weight (g) of vine cuttings after 120 days of planting

\section{Discussions}

The observed good establishment and subsequent better yields obtained under the Soil+CRH conditions could be attributed to the contribution of CRH to the soil (Otoo, Schiwachi, Kikuno, \& Ayankami, 2011). This could be attributed to the contribution of CRH to the physical nature of the system by significantly, influencing depth, texture, structure, porosity and consistency through changing the bulk surface area, pore-size distribution, particle-size distribution, density and packing.

As a means of improving soil productivity, the CRH's negative surface charge directly also retains positively charged nutrients, increases microbial biomass and nutrient cycling and increases the soil's water-holding capacity of the soil. The CRH as a form of biochar has the following effect on the physical changes in the soil including

1. Particle fragmentation: rain and wind, penetration of roots and fungal hyphae, and bioturbation resulting in more surface area for biochemical reactions.

2. Pore size change with adsorption of OM-trapping of different compounds.

At the chemical level the CRH changes the soil through direct release of nutrients. On the soil biota it serves as a habitat for soil microorganisms and also as a substrate for the soil biota.

Recent studies have shown the ability of charred biomass or biochar to improve soil quality, increase crop production and also have a long turnover time in the soil (Lehmann et al., 2003; Chan, \& Xu, 2009; Chintala et al., 2014a). The high surface area and porosity of biochar enable it to adsorb or retain nutrients and water (Chintala et al., 2013a, 2013b), provide habitat for beneficial microorganisms to flourish and reduce the soil's nutrient depletion rate. Biochar also maintains a maximum amount of $\mathrm{C}$ in the soil as a result of its stability against microbial decay (Baldock \& Smernik, 2002; Chintala et al., 2013a, 2014b). Although it is not a fertilizer itself, applying biochar to soil has been shown to improve crop yields and soil fertility, mostly through increasing soil $\mathrm{pH}$ and thus nutrient availability (Major, 2010). As an amendment in soil, biochar can act in similar way to clay or humus particles which with their large specific and negatively charged surface area can absorb large amount of water and non-acid cations (Downie, Crosky, \& Munroe, 2009).

Biochar also reduces leaching of $\mathrm{Na}, \mathrm{Ca}, \mathrm{Mg}, \mathrm{K}, \mathrm{Si}, \mathrm{Cu}$ and $\mathrm{Zn}$ as well as $\mathrm{P}$ by as much as 40 to $70 \%$ (Laird et al., 2008).

The observed trend of good establishment in soil $+\mathrm{CRH}$, coco-peat, soil + sawdust and soil could be attributed to the increase so soil bulk density in that order of importance. The observed poorest yield obtained from soil + sawdust mixture could also be attributed to the low nutrient status of such a mixture. Dunisch, et al., 2006 tested both fresh wood residues and the same residues after they had been carbonized. They found that the carbonized residues (biochar) adsorbed twice as much $\mathrm{N}$ and 100 times more $\mathrm{K}$ than the fresh wood residues. Hence the better performance of all soils containing CRH and even soils with no amendments over soil +sawdust mixture. Biochars have also been proven to have greater absorbent qualities than the original organic material they were made from.

The observed significant variety differences in establishment, percent new shoot development after planting 
vines and yield could be attributed to the inherent genetic potentials of the variety. For instance, variety such as CRI Kukrupa is multiple tubering and this was reflected in the number of tubers generated from the vine cuttings. Again all the late maturing varieties such as Muchumudu, CRI Kukrupa, Dente, Chenchito tend to generate new leaves and sprouts before bulking and hence generate bigger mini tubers.

It has been proven that age of mother plant at which vine cuttings are excised for planting is a very critical component of the vine multiplication technique (Kikuno et al., 2006), with 30-50 days being the recommended period to enhance establishment of the vines and ensure maximum yield, this is however dependent on variety and how vigorous the plants are. Work done in Ghana, suggests that vine cuttings can be excised 8-12 weeks after emergence (Otoo et al., 2011). The nutrient status of the mother plant is also very critical to enhance establishment of the excised vine.

Boosting of nutrient status of the mother plant through supplemental nutrient application before excising the vines for planting greatly enhanced all parameters studied. This was especially so in the early maturing varieties such as Mankrong Pona, CRI Pona, and Pona, which did not develop new shoots after planting and started bulking immediately after planting. The nutrient boost enhanced their capacity to establish and subsequently yield. For the late maturing varieties a thick canopy was formed which increased their photosynthetic capacity and resulted in high yields.

\section{Conclusions}

All in all, boosting the nutrient status of the mother plant before excision of vine cuttings enhanced the establishment of the vine cuttings and subsequent yield of the minitubers. Vine cuttings must be done 8-12 weeks after emergence of the plant. The vines must be planted in a planting media with biochar (CRH) and subsequently boosted with foliar application of high $\mathrm{P}$ and $\mathrm{K}$ to enhance nutrients absorption and bulking. The efficiency of the vine multiplication is also variety dependent. All the varieties responded positively to the vine multiplication technique. However, the degree of responsiveness differed with CRI Pona being more responsive and Serwa least responsive.

\section{Reference}

Adu, S. V., \& Asiamah, R. D. (1992). Soils of the Ayensu-Densu Basin, Central, Eastern and Greater Accra Regions of Ghana (No. 9, p. 117). Council for Scientific and Industrial Research (CSIR) - Soil Research Institute Memoir.

Aighewi, B. A., Akoroda, M. O., \& Asiedu, R. (2002). Seed yam (D. rotundata, Poir) production, storage and quality in selected yam zones of Nigeria. Africcan J. Root and Tuber Crops, 5(1), 20-23.

Ayankanmi, T. G., \& Agele, S. O. (2010). Effects of Genotype, Root - Promoting Substances and Planting Media on yam (Dioscorea rotundata, Poir) Vine Cuttings for Mini Tuber Production. Advances in Environmental Biology, 4(3), 353-359.

Baldock, J. A., \& Smernik, R. J. (2002). Chemical composition and bioavailability of thermally altered Pinus resinosa (Red pine) wood. Organic Geochemistry, 33(9), 1093-1109. http://dx.doi.org/10.1016/S0146-6380(02)00062-1

Bhattacharjee, R., Gedil, M., Sartie, A., Otoo, E., Dumet, D., Kikuno, H., ... Asiedu, R. (2011). Dioscorea. In C. Kole (Ed.), Wild Crop Relatives: Genomic and Breeding Resources. Industrial Crops. http://dx.doi.org/10.1007/978-3-642-21102-7_4

Chan, K. Y., \& Xu, Z. (2009). Biochar: Nutrient properties and their enhancement. In J. Lehmann \& S. Joseph (Eds.), Biochar for environmental management. Earthscan.

Chintala, R., Mollinedo, J., Schumacher, T. E., Malo, D. D., Papiernik, S., Clay, D. E., \& Gulbrandson, D. W. (2013a). Nitrate sorption and desorption by biochars produced from microwave pyrolysis. Microporous and Mesoporous Materials, 179, 250-257. http://dx.doi.org/10.1016/j.micromeso.2013.05.023

Chintala, R., Owen, R. K., Schumacher, T. E., Spokas, K. A., McDonald, L. M., Malo, D. D., \& Bleakley, B. (2014). Denitrification kinetics in biomass and biochar amended soils of different landscape positions. Environmental Science and Pollution Research. http://dx.doi.org/10.1007/s11356-014-3762-2

Chintala, R., Schumacher, T. E., Kumar, S., Malo, D. D., Rice, J., Bleakley, B., \& Gu, Z. R. (2014b). Molecular characterization of biochar materials and their influence on microbiological properties of soil. Journal of Hazardous Materials, 279, 244-256. http://dx.doi.org/10.1016/j.jhazmat.2014.06.074

Chintala, R., Schumacher, T. E., McDonald, L. M., Clay, D. E., Malo, D. D., Clay, S. A., \& Julson, J. L. (2013b). 
Phosphorus sorption and availability in biochars and soil biochar mixtures. CLEAN-Soil Air Water, 41(9999), 1-9.

Downie, A., Crosky, A., \& Munroe. P. (2009). Physical Properties of Biochar. Biochar for Environmental Management: Science and Technology (pp. 13-32). London, UK.

Dunisch, O., Valmiqui, C. L., Gunther, S., Johannes, D., Valdinez, R. M., \& Schwarz, T. (2007). Retention properties of wood residues and their potential for soil amelioration. Wood Sci Technol., 41, 169-189. http://dx.doi.org/10.1007/s00226-006-0098-1

Glaser, B. (2001). The 'Terra Preta' phenomenon: A model for sustainable agriculture in the humid tropics. Naturwissenschaften, 88, 37-41. http://dx.doi.org/10.1007/s001140000193

Glaser, B., Guggenberger, G., \& Zech, W. (2002). Past anthropogen anthropogenic influence on the present soil properties of anthropogenic dark earths (Terra Preta) in Amazonia (Brazil). Geoarcheology. Retrieved from http://www.biocharinternational.org/images/Laird_nutrient_leaching.pdf

Ironkwe, A. G. (2005). Women participation in the transfer of yam minisett technology in Southern Nigeria. MSc Michael Okpara University of Agriculture Umudike, Nigeria.

Kikuno, H., Muamba K., Shiwachi, H., Micho, O., \& Asiedu R. (2006). Minituber production of white yam (D. rotundata) using vines. Japanese Journal of Tropical Agriculture, 50(Extra Issue 1), 1-3.

Laird, D., Fleming, P., Karlen, D., Horton, R., \& Wang, B. (2008). Impact of Soil Biochar Applications on Nutrient Leaching. USDA and Agricultural Research Service.

Lehmann, J., \& Joseph, S. (2009). Biochar for Environmental Management. Earthscan, London.

Lehmann, J., da Silva Jr., J. P., Steiner, C., Nehls, T., Zech, W., \& Glaser, B. (2003). Nutrient availability and leaching in an archaeological Anthrosol and a Ferrasol of the Central Amazon basin: Fertilizer, manure and charcoal amendments. Plant and Soil, 249, 343-357. http://dx.doi.org/10.1023/A:1022833116184

Major, J. (2010). Biochar belongs in the soil. Retrieved March 19, 2010, from http://www.nscss.org/node/187

Manyong, V. M. (2000). Farmers' perception of the resource management constraints in yam-based systems. Improvement of yam based systems. Annual Report 1999. IITA Ibadan.

Otoo, E., Hironobu S., Hideniko, K., \& Ayankami, T. (2011). Preliminary Studies into the Use of Vine Multiplication Technique in Yam (Dioscorea Spp.) Seedyam Generation. West Africa Root and Tuber Conference, Mensvic, September 12-16, 2011.

Otoo, J. A. (1980). Effect of staking, fertilizer and spacing on seed yam yields. GAINS on-line.

Peter, K. V. (2006). Underutilized and underexploited Horticultural Crops (Vol. 1, p. 378). New India Publishing Agency, New Delhi.

Zimmerman, A. (2009). Biochar stability in the environment. Conference Presentation at the North American Biochar Conference, August 9-12, 2009, Colorado, USA.

\section{Copyrights}

Copyright for this article is retained by the author(s), with first publication rights granted to the journal.

This is an open-access article distributed under the terms and conditions of the Creative Commons Attribution license (http://creativecommons.org/licenses/by/3.0/). 